Columbia Law School

Scholarship Archive

1999

\title{
Rethinking the Uniformity Norm in Commercial Law: Optimal Institutional Design for Regulating Incomplete Contracts
}

Robert E. Scott

Columbia Law School, rscott@law.columbia.edu

Follow this and additional works at: https://scholarship.law.columbia.edu/faculty_scholarship

Part of the Contracts Commons

\section{Recommended Citation}

Robert E. Scott, Rethinking the Uniformity Norm in Commercial Law: Optimal Institutional Design for Regulating Incomplete Contracts, UNIVERSITY OF VIRGINIA LAW SCHOOL LEGAL STUDIES WORKING PAPER No. 99-9 (1999).

Available at: https://scholarship.law.columbia.edu/faculty_scholarship/1185

This Working Paper is brought to you for free and open access by the Faculty Publications at Scholarship Archive. It has been accepted for inclusion in Faculty Scholarship by an authorized administrator of Scholarship Archive. For more information, please contact scholarshiparchive@law.columbia.edu. 


\title{
UNIVERSITY OF VIRGINIA SCHOOL OF LAW Legal Studies Working Papers Series
}

\author{
Rethinking the Uniformity Norm in \\ Commercial Law: Optimal Institutional \\ Design for Regulating Incomplete Contracts
}

\author{
Robert E. Scott
}

Working Paper No. 99-9

June 1999

This paper can be downloaded without charge from the Social Science Research Network Electronic Paper Collection: http://papers.ssrn.com/paper.taf?abstract_id=169276 


\title{
RETHINKING THE UNIFORMITY NORM IN COMMERCIAL LAW Optimal Institutional Design for Regulating Incomplete Contracts
}

\author{
Robert E. Scott*
}

\section{Introduction}

One of the central norms of the Uniform Commercial Code is "to make uniform the law among the various jurisdictions." 1 Nowhere in the Code, however, is the substance of the uniformity norm of commercial law explained or justified. Moreover, in the thirty years following the widespread adoption of the Code in all American jurisdictions ${ }^{2}$, there has been virtually no academic or judicial analysis of whether this grand experiment in the uniform codification of American commercial law has, in fact, produced the social benefits that are presumed to follow from uniformity. Instead, there is a broad consensus, uninformed by evidence or analysis, that formal uniformity has led to substantive uniformity, to the certainty, predictability and stability that are the bedrock desiderata of commercial law.

This uncritical acceptance of the notion that uniform codification best promotes substantive uniformity is puzzling. Large areas of commercial contract law and corporate law remain outside the Code and have evolved in a formally non-uniform fashion through the process of common law adjudication and statutory enactments in various states. In the case of corporate charters, a robust literature has focused on the substantive benefits inherent in jurisdictional diversity--stimulating a "race to the top" as states compete among themselves to capture the

*Dean and Lewis F. Powell Jr. Professor of Law, University of Virginia.

I am thankful to John Jeffries, Bill Stuntz and Steve Walt for their helpful comments on prior drafts.

${ }^{1}$ Section 1-102(2)(c)

${ }^{2}$ By 196_, the Code had been adopted in 49 states and the District of Columbia. The only exception to formal uniformity was Louisiana, where adoption of most parts of the Code has occurred more recently. 
economic rents from incorporation. ${ }^{3}$ Many of these substantive benefits, such as predictable interpretation of corporate charters and the promulgation of standardized contract terms, are precisely the values that inhere in any sensible conception of what the uniformity norm entails. ${ }^{4}$

Clearly, then, uniform codification is not the only institutional design for promoting substantive uniformity. Nor is it a priori preferable or superior to the common law alternative. The experience of the last forty years does provide us the opportunity to conduct a natural experiment: to compare the uniform code and the common law against plausible optimality criteria that undergird the norm of uniformity. This essay begins that project.

I begin with the claim that the state's primary substantive role in uniformly enforcing commercial contracts is to regulate incomplete contracts efficiently. This role requires the state to perform two interdependent but conceptually distinct functions. The first is an interpretive function--the task of correctly (and uniformly) interpreting the meaning of the contract terms chosen by the parties to allocate contract risk. The second is a standardizing function--the task of creating broadly suitable default rules and/or "labeling" widely used contract terms (or combinations of terms) with standard meanings. Correct interpretation argues for a "textualist" or plain meaning interpretation of the express terms used in incomplete contracts. ${ }^{5}$ The task of generating useful defaults argues, on the other hand, for contextualizing incomplete contracts. The defaults will naturally come from commercial practice, and context evidence is the way courts find out about commercial practice. Thus, the first goal seems to require keeping context out

${ }^{3}$ See, e.g., Roberta Romano, Law as a Product; Some Pieces of the Incorporation Puzzle, 1 J. Law, Econ. \& Org. 224 (1985); William J. Carney, The Production of Corporate Law, 71 S. Cal. L. Rev. 715 (1998); Roberta Romano, the Genius of American Corporate Law (1993); Ronald J. Daniels, Should Provinces Compete?: The Case for a Competitive Corporate Law Market, 36 McGill L.J. 130 (1993).

${ }^{4}$ Marcel Kahan \& Michael Klausner, Standardization and Innovation in Corporate Contracting (Or "the Economics of Boilerplate"), 83 Va. L. Rev. 713 (1997).

${ }^{5}$ For the same reason, textualists in other areas of law, like statutory interpretation, argue against using context evidence such as legislative history to illuminate the text. 
whenever possible, and the second goal seems to require incorporating context as often as possible. As a consequence, the law is apparently forced to trade off one goal against the other.

The UCC has quite clearly chosen the strategy of incorporation. In addition to a broad definition of the meaning of a legally binding agreement ${ }^{6}$, it adopts a pervasive standard of commercial reasonableness that requires context to supply meaning to many of its generic default rules. But curiously, the Code fails even at the one task it was explicitly designed to do. Under the Code, there has been very little production of standardized defaults. Moreover, the Code, intent on incorporation, fails at the first enterprise--reliable and predictable interpretation of contractual text. On the other hand, the development of standardized defaults has been much more successful under the common law, in those areas of contract law such as commercial services to which the Code does not extend. And these courts have also retained more traditional plain meaning and parol evidence rules and thus have maintained and reinforced their textualist interpretive strategy. The result is that both kinds of efficiency gains--the creation of a fairly uniform menu of standardized defaults, with regular additions of new terms to the menu, and stable (i.e., uniform) interpretation of express terms-- are seen much more in the common law than under the Code.

In sum, the great exercise in promoting codified uniformity and predictability has instead produced variety and greater contracting risk. In part, this is a problem caused by the way in which the Code is drafted and especially with the pervasive emphasis on commercial reasonableness. But in a larger sense, the inefficiencies of the Code are a product of the codification enterprise itself --of trying to introduce a civil-law approach into a largely successful common law system. A code remains at all times its own best evidence of what it means. Thus, decisions interpreting specific contract terms and default rules of the Code do not as easily

\footnotetext{
${ }^{6}$ See UCC Section 1-102(3). An "agreement" means the bargain of the parties in fact as found in their language or by implication from other circumstances including course of dealing or usage of trade or course of performance..." Comment 3 explains that the Code's concept of agreement is intended to include full recognition of all context evidence and the surrounding circumstances.
} 
become part of the understood, standardized meaning. Because gaps are filled with reference to the internal policy of the Code rather than the external contractual context, interpretation is both contextual and self-referential--the worst of both worlds. ${ }^{7}$

The paper proceeds as follows. Part I specifies the efficiency objectives of a uniform commercial law. Part II compares the experience of contracting parties under the Code (with particular emphasis on sales law ) with the roughly parallel experience of commercial parties who negotiate and litigate contracts under the common law. I evaluate the results of this natural experiment in terms of the uniformity criteria developed in Part I. Surprisingly, uniform codification appears to be an inferior institutional design to the modern common law alternative. In Part III, I argue that a principal reason why the UCC is less "uniform" than the common law stems from the uniquely different interpretive methodology and institutional design that is dictated by a code. Thus, while the Code has achieved a formal jurisdictional uniformity it has failed to enhance substantive uniformity: the Code forces a contextualist interpretation of express terms in incomplete contracts, but it does so without securing the offsetting benefits of standardization.

${ }^{7}$ For a discussion of what it means to call the UCC a "true" code, see note 60 infra. 


\section{THE ROLE OF THE STATE IN UNIFORMLY REGULATING INCOMPLETE CONTRACTS}

The central task of a uniform commercial law is to specify the appropriate role of the state in regulating incomplete contracts. Complete contracts are rarely, if ever, breached since the payoffs for every relevant action and the corresponding sanctions for non performance are prescribed. In the case of incomplete contracts, parties have incentives to breach to exploit contractual gaps. Making the verifiable terms of the contract legally enforceable and regulating incompleteness in a consistent manner reduces these incentives to breach. Legal enforcement of incomplete contracts thus requires the state to interpret the signals the contracting parties have used to allocate contractual risk. Interpreting disputed contracts also presents the state with the opportunity to protect (and even improve) the efficacy of those signals for future contractors. If the state performs this function in an inconsistent manner the costs of contracting will rise.

\section{The Efficiency Values of Uniformity}

To regulate incomplete contracts efficiently, the state must consistently or "uniformly" perform two interdependent but conceptually distinct functions. The first is an interpretive function--the task of uniformly interpreting the contract terms chosen by contracting parties to allocate contract risk. An interpretation is 'uniform' when it is transparent to the litigating parties and predictable to other parties. ${ }^{8}$ An important point, often lost on those who promote formal

${ }^{8}$ This principle is vividly captured in Judge Learned Hand's famous dictum:

"A contract has, strictly speaking, nothing to do with the personal, or individual, intent of the parties...If it were proved by twenty bishops that either party, when he used the words, intended something else than the usual meaning which the law imposes upon them, he would still be held...."

Hotchkiss v. National City Bank, 200 F. 287, 293 (S.D.N.Y. 1911), aff'd, 201 F.2d 664 (2d Cir. 1912), aff'd, 231 U.S. 50 (1913). See also, the court's statement in Chernohorsky v Northern Liquid Gas Co:

"The language of a contract must be understood to mean what it clearly expresses. A court may not depart from the plain meaning of a contract where it is free from ambiguity. In construing the terms of a contract, where the terms are plain and unambiguous, it is the duty of the court to construe it as it stands, even though the parties may have placed a different construction on it."

Chernohorsky v. Northern Liquid Gas Co., 268 Wis. 586, 68 N.W. 2d 429 (1955); Restatement of Contracts sec. 230 comment b (1932); 4 S. Williston, A Treatise on the Law of Contracts, Sec. 609, at 403-04 n.2 (citing supporting cases). 
uniformity, is that uniform interpretation is both a temporal as well as a jurisdictional matter. Thus, one efficiency value is for parties to know at the time they write contracts that their verifiable obligations will be interpreted in the same manner by courts of different jurisdictions (jurisdictional uniformity). In addition, efficiency is enhanced if parties are certain that courts in any given jurisdiction will interpret their verifiable obligations uniformly over time (temporal uniformity).

The interpretive task is made difficult in incomplete contracts because the causes of incompleteness are not known to the interpreter. Did the parties fail to complete the contract deliberately or inadvertently? Is the incompleteness a product of high transaction costs or of endogenous factors? If the incompleteness is a result of endogenous factors, those factors may be the inability of the parties who can observe relevant variables to verify those variables to courts or they may be the unwillingness of the parties to disclose to others the relevant information necessary to verification. For these reasons, an interpreter seeking to understand the causes of incompleteness in any particular case can only sensibly rely on the signals chosen by the parties. Predictability of meaning is the bedrock of any signaling system. This latter requirement argues for the use of objective interpretive methodologies so that parties can predict over time the effect to be given to the words used to create obligations. Thus, objective modes of interpretation and temporal uniformity go hand-in-hand.

The second function of uniform state regulation is standardization. At least to the extent that this task is also performed by courts, it is interdependent with and derivative of the interpretive function. The state facilitates the contracting process to the extent that courts in the process of interpretation create standardized (or 'uniform') terms that parties can use in signaling their intentions so as to remove the uncertainties attendant on interpretation. Those signals can be developed in two ways. The first is through a process of "gap filling", where courts interpreting incomplete contracts elect to condition or qualify the express terms of the contract by specifying default rules that complete the contract. These default rules can be broadly suitable 
"majoritarian" defaults that apply to the largest set of heterogenous contractors, or they can be "tailored" defaults that apply to smaller subsets of homogeneous parties (such as merchants in a particular trade or business). The second method of standardization occurs when courts interpret authoritatively the meaning of widely used express terms ("invocations") or combinations of express terms ("conventions") in incomplete contracts. In either case, the key to this process is the standardization of the meaning and jurisdiction of the relevant defaults and of the menu of express invocations or conventions from which parties can customize their contracts.

As a matter of institutional design, these two functions can be performed separately--e.g., where courts interpret incomplete contracts and legislators generate useful defaults and menus of invocations or conventions-- or they can be performed in combination --e.g., where courts fill gaps and interpret litigated contracts and thereby attach standard meanings to defaults, invocations and conventions. But in either case, the performance of the one role necessarily effects the performance of the other. Evaluating these efficiency objectives of state regulation is further complicated in American law because, as I suggested above, there are two quite different dimensions of nonuniformity. The first dimension is principally temporal. It assumes a single state decision maker and looks to consistency and standardization over time. A quite different dimension of the problem is embodied in jurisdictional uniformity, which focusses on consistent decision making by different courts in different jurisdictions. For expository clarity, I will designate both dimensions as comprising "substantive" uniformity. Substantive uniformity should be distinguished from purely formal uniformity, e.g., the coincidence of similar rules across time and across jurisdictions.

While the complexity of the task of uniformly regulating incomplete contracts is better understood today, policy makers have long seen the critical importance of predictability of outcomes and certainty of meaning given to both the express and implied terms in commercial law. Indeed, perhaps the oldest aphorism in commercial law is that in commercial contexts it is more important for the law to be certain than to be right. This aphorism has its roots in the law 
merchant and found new voice in the United States where commercial law was first established in the diversity of different states accepting the English Common Law at different times and with different interpretations of the content and meaning of that law. ${ }^{9}$

\section{The Uniformity Movement in Commercial Law}

Despite the diversity of jurisdiction and legal heritage in the United States, a recognizable trend toward uniformity in commercial law quickly took hold. Grant Gilmore observed the effects of Swift v. Tyson on commercial law in the nineteenth century:

During the second half of the nineteenth century, the Supreme Court of the United States became a great commercial court. The rules which it announced were, in nine cases out of ten, gladly followed by the state courts as well as, of course, by the lower federal courts. A remarkable degree of national uniformity in the law applicable to commercial transactions was in fact achieved over a remarkably long period of time. ${ }^{10}$ Nevertheless, the degree of uniformity achieved by this 'common law' process was seen as inadequate. Significant diversity in the commercial law of various states led to calls for the enactment of a federal commercial code to govern interstate commercial transactions. ${ }^{11}$

The calls for a federal code stimulated the formation of the National Conference of Commissioners on Uniform State Laws in 1892. ${ }^{12}$ Rather than accepting federal intrusions into a traditional preserve of state authority, the National Conference proposed to formulate and seek adoption of various uniform laws governing different aspects of commercial law. Each state was

${ }^{9}$ Hall, The Common Law: An Account of its Reception in the United States, 4 Vand. L. Rev. 791 (1951).

${ }^{10}$ Gilmore, Commercial Law in the United States: Its Codification and Other Misadventures, in Aspects of Comparative Commercial Law: Sales, Consumer Credit, and Secured Transactions 449, 454 (J. Ziegel \& W. Foster 1969)

${ }^{11}$ See, e.g., Committee on Commercial Law, Report, 10 ABA Rep. 332, 332-44 (1887); See generally, Taylor, Federalism or Uniformity of Commercial Law, 11 Rutgers-Camden Law Journal, 527 (1980).

${ }^{12}$ Handbook of the National Conference of Commissioners on Uniform State Laws (1892). 
then encouraged to adopt these uniform statutes. Unhappily for the Conference, the uniform acts received a mixed reception in the states. All states adopted the Uniform Negotiable Instruments Law and the Uniform Warehouse Receipts Act. But only thirty states adopted the Uniform Sales Act and only ten enacted the Uniform Conditional Sales Act.

The result of the first efforts to produce uniform state commercial law was seen as unsuccessful in terms of the key criteria of predictability of interpretation and standardization of legal rules. Widely noted were the prevalence of local amendments to uniform acts and interpretational differences among the various state courts. The perceived failure of the states' processes to perform adequately the substantive purposes underlying the drive for uniformity stimulated reform initiatives. In 1940, the Federal Sales Act was introduced in Congress. The federal act received strong support from influential academics and practitioners. ${ }^{13}$ The National Commissioners reacted to the threat of federalization with predictable speed. They lobbied against federal enactment, began the drafting of a revised Uniform Sales Act and, perhaps most significantly, recruited to their task, Karl Llewellyn, one of the strongest advocates for the federalization of sales law.

By 1945, the NCCUSL had formed a collaboration with the American Law Institute and, working in tandem, they expanded the revised sales act project to include the drafting of a comprehensive Uniform Commercial Code. Llewellyn and the other proponents of the project sought to avoid the difficulties with the previous experiment in state law uniformity by creating a 'code' in a true sense -- a systematic, preemptive and comprehensive enactment of a whole field of law. ${ }^{14}$ The decision to produce a code was primarily instrumental. The ALI and NCCUSL believed that this consolidation would enable them to sell the entire project to the states on a "take it or leave it" basis and thus avoid the selective enactment that had occurred with the earlier

\footnotetext{
${ }^{13}$ See generally, Llewellyn, The Needed Federal Sales Act, 26 Va. L. Rev. 558 (1940); Thomas, The Federal Sales Bill as Viewed by the Merchant and the Practitioner, 26 Va. L. Rev. 537 (1940).

${ }^{14}$ See note 60 infra for a discussion of the status of the Code as a "code".
} 
uniform acts. ${ }^{15}$ The strategy worked. By 1967, every American state except Louisiana had adopted the Code. ${ }^{16}$

In a formal sense, uniformity in commercial law has been achieved. But the success of the Code in gaining widespread and "uniform" adoption has disguised a deeper jurisprudential question. To what extent have the efficiency goals of uniformity--predictability of interpretation and standardization of widely useful terms-- been served by the experiment in codification of commercial law? Before we can address that question systematically, we must first examine more carefully the interdependencies that affect those two central roles of state regulation.

\section{The Dilemma of Substantive Uniformity}

The traditional assumption that uniform law straightforwardly promotes the efficient regulation of incomplete contracting is, at best, simplistic and, at worst, seriously misleading. To the extent that the uniformity norm purports to embrace both predictable interpretations of incomplete contracts as well as the standardization of contract terms, it is subject to an apparent dilemma: achieving predictability in interpretation appears to undercut the process of standardization and vice versa. This dilemma is rooted in the fundamental tensions that exist between express terms and default rules and between standard and unconventional forms of expression.

To the extent that these tensions have been understood at all, the major attempt to harmonize them relies on what I have elsewhere termed the expanded choice postulate. ${ }^{17}$ The postulate maintains that default rules (as well as menus of contract terms) expand contractors

\footnotetext{
15 William D. Hawkland, The Uniform Commercial Code and the Civil Code, 56 La. L. Rev. 231, 232-35 (1995).

${ }^{16}$ By 1975, Louisiana had enacted Articles 1,3,4 and 5. Subsequently, Article 9 and parts of Article 2 were enacted as well.

${ }^{17}$ Charles J. Goetz \& Robert E. Scott, The Limits of Expanded Choice: An Analysis of the Interactions Between Express and Implied Contract Terms, 73 Calif. L. Rev. 261, 262 (1985).
} 
choices by providing standardized and widely suitable contract terms that reduce the cost and error involved in individually negotiating a complete contract. This expanded choice thesis implicitly presumes a neutral stance toward individualized agreements: atypical parties lose nothing, since they remain free to opt out of the standard defaults and/or design customized provisions to replace the state sanctioned terms.

But the seductive appeal of the expanded choice postulate serves to disguise its unacknowledged incongruities. For example, creating useful defaults by filling gaps in incomplete contracts may lead to misinterpretation of the express terms of the contract. On the other hand, strict adherence to a textualist or plain meaning interpretation of the express terms in an incomplete contract may diminish the supply of useful defaults that will have received official "recognition". These and other related problems expose a central question that challenges the simple form of the uniformity norm: to what extent do express terms and default rules, and standardized and individualized forms of agreement function in antagonistic rather than complementary ways?

The Benefits of Standardization. Standardized terms exist both as default rules and as standard terms and forms (express invocations and conventions). The state's provision of standardized defaults, invocations and conventions reduces many errors that inhere in incomplete contracting. Providing a menu of signals from which parties can choose greatly simplifies and reduces the cost of contracting. It is important to realize, however, that the benefits of standardization go far beyond a mere savings of these additional resource costs. Standardized terms bring a collective wisdom and experience that parties are unable to generate individually.

The unique benefits of standardization derive from the process by which such terms mature and are recognized by the state as having consistent meaning. A principal effect of this evolutionary process is the testing of combinations of express terms and default rules for latent defects. Combinations of terms in incomplete contracts are unlikely to be carefully pretested by 
individual contractors; testing involves substantial risks and private parties who develop successful packages of contractual terms cannot capture much of the benefit that will accrue to subsequent users. Thus, the state's recognition of the evolutionary trial and error process functions as a regulatory scheme designed to promote these public goods. Over time, the consequences of standard formulations are observable in a wide range of transactions, permitting the identification and removal of errors of ambiguity, inconsistency or incompleteness. ${ }^{18}$

Standardization thus provides a reliable and uniform (and therefore intelligible) system of signaling to courts the nature of the contractual risk assumed by each party. It also contributes to the evolutionary enrichment of the supply of novel terms through the selection and announcement of specific experiences that can be generalized to particular classes of transactions. By expanding the stock of such tailored defaults, the state provides parties with better fitting default choices. Taken in combination, these several benefits argue for more rather than less standardization. However, the gains from standardization are purchased at considerable cost. First, standardization increases the risk that courts will misinterpret the meaning of the express terms that parties use to opt out of the standard defaults. Second, standardized defaults increase the difficulty in coordinating a move to novel default terms. The first problem undermines the objective of predictable interpretation while the second threatens the future supply of useful default terms.

Institutional Bias Against Verifiable Express Terms. Interpretation of incomplete contracts by courts is the traditional medium through which the state incorporates privately developed prototypes into the stock of useful default rules. The evolution of widely useful standardized terms is facilitated by theories of interpretation that use context evidence liberally to supplement both the express terms of an agreement and the state-supplied default rules. This objective clashes, however, with the demands of the second interpretive function: correctly

\footnotetext{
${ }^{18}$ See Goetz \& Scott, The Limits of Expanded Choice, supra note -- at---.
} 
interpreting the verifiable express terms in incomplete contracts. Are these verifiable terms to be interpreted as trumping the default rules and thus given a plain meaning interpretation "as written"? Or are they seen as merely supplementing the defaults and thus to be contingent on default terms that courts deploy to complete the gaps in the contract?

A single-minded focus on increasing the supply of standardized defaults will threaten the integrity of the express terms in the contract because the interpreter will be reluctant to give express terms meanings that conflict with the apparent factual and legal context. One response is for courts to insist --through the rules of interpretation--on certain standards of artful wording. ${ }^{19}$ The bias against interpreting verifiable express terms "as written" (i.e., without recourse to context evidence) will tend to diminish if key words are given well-defined meanings. This means of protecting the building blocks of express agreement requires the interpreter to restrict the weight accorded to any extrinsic evidence that vitiates the predefined or "plain" meaning of certain terms.

Barriers to Innovation. Even assuming that parties can define contract terms so as to escape the standard formulations, standardization impedes the development of novel or innovative terms. A transition to new contractual formulations requires groups of contractors to coordinate their joint adoption of a standard formulation of the novel terms. The limits of copyright law create an initial barrier to innovation by denying parties substantial property rights in their formulations. An inherent collective action problem thus retards the production of novel terms for emerging relationships. So long as individual contractors must bear the costs of novelty but are incapable of capturing the full benefits of their innovative expressions, novel formulations will be underproduced. ${ }^{20}$ Moreover, learning effects (the costs involved in learning how best to use

${ }^{19}$ See Patterson, The Interpretation and Construction of Contracts, 64 Colum. L. Rev. 833 (1964).

20 The costs of innovation include the uncertainty costs of interpretation. New terms, no matter how apt for the parties contracting purposes, carry an enhanced risk that they will be interpreted by courts in a manner different from that intended by the parties. Novel terms also carry a heightened risk of latent ambiguity and other errors of expression. These costs are borne by the initial drafters and remain until the terms have survived litigation and been 
and deploy the novel terms) will discourage parties from adopting the novel terms once they are developed. ${ }^{21}$ Thus, even if private parties could costlessly develop novel uniform terms, they cannot readily coordinate any general move to the new forms by other contractors.

The twin problems of misinterpretation and uncoordinated behavior that are a by-product of the state's effort to provide uniform and standardized terms are a classic illustration of the optimal solution for one segment of a multidimensional problem being inconsistent with the optimal solution for the whole. Standardization, which aims to reduce the costs of contracting, indirectly produces negative effects in a related dimension of the regulatory process. This fact does not, of course, imply that the state's role in facilitating standardized terms is on balance undesirable. It does suggest, however, that the drive toward uniformity in American commercial law has ignored significant trade-offs in the state's regulatory process. ${ }^{22}$ Understanding how best to optimize these trade-offs requires a better understanding of contacting behavior. What are the causes of incompleteness in contracts, and how best can the state assist parties as it performs the dual roles of interpretation and standardization?

\section{Maximizing Solutions to the Uniformity Dilemma}

Assuming that substantive uniformity is a desirable objective for the state, a plausible strategy is to maximize the net social benefits to contracting parties that derive from the dual regulatory functions of interpretation and standardization. But operationalizing this formulation poses significant difficulties. Even assuming that the gains to contractors from "better" interpretation of incomplete contracts can be compared ordinally to the gains to parties from increased standardization, the question remains: how best to strike the balance? And can some

\footnotetext{
“authoritatively” interpreted. See Goetz \& Scott, Expanded Choice, supra note ---at ---.

${ }^{21}$ See Steven Walt, Novelty and the Risks of Uniform Sales Law (1998).

${ }^{22}$ See also Eric Posner, The Parol Evidence Rule, the Plain Meaning Rule, and the Principles of Contractual Interpretation, 146 U. Pa. L. Rev. 533 (1998) (framing this dilemma as a choice between a "hard parol evidence rule" and a "soft parol evidence rule")
} 
types of institutional design achieve that optimum better than others?

The recent theoretical literature on incomplete contracting offers some valuable insights into the reasons for incompleteness and, in turn, suggests a modest and circumscribed role for courts in generating default rules and an expansive role in "recognizing" standardized express terms.

There are, broadly speaking, two classes of reasons why parties might not write complete contracts (contracts that prescribe pay-off relevant actions for every possible state of the world)-transactions costs and asymmetric information. Transactions costs explanations of incompleteness have formed the basis for much of the law-and-economics analysis of contract law. On this account, parties write incomplete contracts because: a) the resource costs to them of writing complete contingent contracts would either exceed their gains or the costs to the state of creating useful defaults, ${ }^{23}$ or b) the parties are unable to identify and foresee uncertain future conditions or are incapable of characterizing complex adaptations adequately. ${ }^{24}$

If transactions costs are preventing the parties from completing contracts with efficient terms, then the state properly should supply defaults to solve those problems when the state's costs are lower than the parties. Much of the recent contract theory literature argues, however, that these conditions are hard to satisfy in a large economy with heterogenous parties. ${ }^{25}$ Under these conditions, many factors suggest a modest state role--the more heterogenous are the contracting parties, the less the scale economies for any default and the greater the likelihood that the state is less capable than the parties themselves in solving their contracting problems. Unless

\footnotetext{
${ }^{23}$ See Charles J. Goetz \& Robert E. Scott, Liquidated Damages, Penalties and the Just Compensation principle: Some Notes on a Theory of Efficient Breach, 77 Colum. L. Rev. 554 (1977).

${ }^{24}$ See Goetz \& Scott, Principles of Relational Contracts, 67 Va. L. Rev. 1089 (1981).

${ }^{25}$ Alan Schwartz, The Default Rule Paradigm and the Limits of Contract Law, 3 S. Cal. Interdisciplinary L. J. 389 (1994)
} 
the contracting solution is immanent in the commercial practice and relationship of the parties (as Llewellyn believed it was), and a court can identify and standardize the practice or experience as a default, a court is likely to create ill-fitting defaults in complex commercial environments.

Asymmetric information is the second reason why contracts are incomplete. A contract is incomplete owing to such endogenous factors when one of the parties cannot observe key economic variables either at the time of contracting or upon renegotiation, or because they cannot verify those variables to courts, or because they choose for strategic reasons not to disclose private information about themselves. ${ }^{26}$ When these conditions obtain, parties will choose to write incomplete contracts even if transactions costs are zero. The possibility that contracts are incomplete because of endogenous factors urges even greater modesty about the state's role in creating useful default rules. The state is incapable of completing contracts with useful defaults whenever contracts are endogenously incomplete. A default would have to be conditioned on information that is unobservable to the parties and/or unverifiable to the courts. Since contracting parties will not condition their contracts on information that is unobservable or unverifiable, they would opt out of any such state-supplied defaults. Put another way, the state cannot write better contracts than the parties can for themselves in a world of zero transactions costs. Under these conditions the state simply cannot provide parties with useful defaults that solve their contracting problems. ${ }^{27}$

This analysis suggests that the role courts may have traditionally assumed in specifying default rules for contracting parties may be far less useful in a complex economy, unless the courts have the capacity to craft tailored defaults by efficiently incorporating commercial practice and experience for commercial subgroups. Moreover, the invitation to courts to seek to

\footnotetext{
${ }^{26}$ Alan Schwartz, Incomplete Contracts, The New Palgrave Dictionary of Economics and Law (1997); Ian Ayres \& Robert Gertner, Strategic Contractual Inefficiency and the Optimal Choice of Legal Rules, 101 Yale L. J. 729 (1992); Hermalin and Katz, Judicial Modification of Contracts between Sophisticated Parties: A More Complete View of Incomplete Contracts and their Breach, 9 J. Law Econ \& Org. 98 (1993).

${ }^{27}$ Schwartz, Incomplete Contracts, supra note--- at ----.
} 
advance the standardization goal by creating broadly useful defaults threatens the parallel goal of predictable interpretation, especially when incompleteness is a product of asymmetric information. Thus, for example, parties may write incomplete contracts that look to renegotiation as the mechanism for achieving ex post efficiency. Under these conditions, the verifiable price and quantity terms in an otherwise incomplete contract may well be designed to form the basis for ex post renegotiation. A court that conditions the enforceability of the price and quantity terms of the contract by completing the contract with a default rule is changing the agreed upon parameters of the renegotiation game.

Does this mean that there is no role for state-facilitated standardization in a complex environment of incomplete contracting? The answer is certainly no. A clue to the solution to the vexing problem of regulating incomplete contracts lies in the fact that heterogeneity of both contracting behavior and of contracting parties argues for preserving the objective instruments for interpreting contracts. Given the difficulty of identifying whether incompleteness is a consequence of high transactions costs or of asymmetric information, and assuming that the state cannot efficiently incorporate the commercial norms necessary to supply useful tailored defaults, the best option is for courts to interpret the verifiable terms of the contract without recourse to extrinsic evidence. Thus, a given form of words will come to have a given meaning that will hold across cases. Not only would this goal preserve the uniformity value of predictable interpretation, but, insofar as courts authoritatively interpret commonly used express terms, it advances the standardization norm by expanding the menu of express invocations and conventions.

In sum, the maximizing solution to the regulation of incomplete contracts suggested by this analysis is for the state to embrace the single-minded institutional goal of motivating improvements in the express invocations and conventions that constitute the defining instruments parties use in writing contracts. A rigorous application of the plain meaning rule will reduce interpretation error by encouraging more careful choices of clear standardized signals. Over time, a menu of these express invocations and conventions will be developed by private parties, 
authoritatively interpreted by the courts, and thereby standardized for widespread adoption by other parties with similar contracting problems.

The cost of this institutional design is the inability of courts, barred from evaluating the commercial context, to incorporate the customary prototypes that typify a particular commercial context and that might otherwise emerge as tailored defaults. The merits of the strategy thus turn on a straightforward empirical question. To what extent does ( or can) efficient incorporation occur? In the absence of efficient incorporation, a strategy of plain meaning interpretation would maximize the interpretation and standardization values inherent in the uniformity norm. Evidence of incorporation of commercial norms by courts under the Code would thus suggest that the theoretical skepticism about judicial creation of useful defaults may be unwarranted. On the other hand, evidence that courts under the Code do not (or can not) use the incorporation mechanism to create tailored defaults would lend credence to the more modest role suggested by the recent theoretical literature. 


\section{EVALUATING SUBSTANTIVE UNIFORMITY UNDER THE CODE AND COMMON LAW}

The question of whether the Code or the common law best achieves the efficiency goals that inhere in uniformity is amenable to observation since we now have thirty years experience with sales law under the Code against which we can compare a roughly parallel experience with the common law regulation of commercial services contracts. The state plays a relatively restrained role in supplying standardized defaults under the traditional common law approach to interpretation and incorporation. The common law interpretive approach, as reflected in the parol evidence and plain meaning rules, focuses intensively on the written agreement. ${ }^{28}$ If the writing appears to be a complete expression of the parties' agreement, the common law parol evidence rule bars introduction of contextual evidence to contradict or even supplement the written terms. ${ }^{29}$ Only the established set of judicially or legislatively recognized default rules (the law of contract) are automatically incorporated into the agreement. In addition, the traditional plain meaning rule bars parties from using contextual evidence to aid in the interpretation of contract terms that appear clear and unambiguous on their face, giving instead a lay or "dictionary" meaning to the words used.

Quite clearly, the traditional common law approach to interpretation and incorporation resolves the uniformity dilemma by sacrificing the possible benefits from increasing the supply of standardized defaults in order to preserve the benefits from predictable, "objective" interpretation. But what if the incorporation process could be deployed efficiently to discover and then promulgate as tailored defaults, experiences and practices derived from the general commercial

\footnotetext{
${ }^{28}$ See e.g., Henrietta Mills Inc. v. Commissioner, 52 F.2d 931,934 (4th Circ. 1931) ("the courts will not write contracts for the parties to them nor construe them other than in accordance with the plain and literal meaning of the language used.”); See also, Farnsworth, Disputes over Omission in Contracts, 68 Colum. L. Rev. 860, 862-64 (1968).

${ }^{29}$ See e.g., Smith v. Abel, 316 P.d. 146,148 (Ore. 1957) ("While custom, if sufficiently shown, might be used to interpret an ambiguous term in the contract, it could not be used to make a contract or to add to or contradict the terms of the contract."); Swiss Credit Bank v. Board of Trade, 597 F2d. 146, 148 (9th Cir. 1979) (ambiguity is necessary to admission of usage evidence).
} 
environment? Such useful defaults might include trade usages regarding the existence of warranties, commonly accepted quality tolerances, and circumstances under which price and quantity terms that appear to be fixed are in fact subject to some variation. These customary norms can serve as prototypes; as temporal precursors to formal legal recognition. If incorporation could be efficiently deployed in that manner, it would argue for a more balanced approach to maximizing substantive uniformity-- trading off some of the gains from plain meaning interpretation so as to facilitate incorporation of useful defaults for commercial subgroups.

It is precisely that intuition that appears to undergird Llewellyn's notion of "immanent" law. Llewellyn saw the law as the crystallization of slowly evolving social mores. A just law was inherent in the patterns of relationships that one could observe and record in the commercial environment. From this perspective, the role of courts was not deductive, but inductive: to observe and record what was already there. ${ }^{30}$ Thus the Code, buttressed by Llewellyn's jurisprudential intuitions, purports to offer a dramatically different, activist approach to the uniformity dilemma. The Code purports to reverse the common law presumption that the parties writings and the official majoritarian default rules (the law of contract) are the definitive elements of the agreement. Rather the Code explicitly invites incorporation by defining the content of an agreement to include trade usage, prior dealings and the parties experiences in performing the contract. Indeed, the Code rejects the plain meaning rule,$^{31}$ and its parol evidence rule admits inferences from usage, prior dealings and contractual performance even if the express terms of the contract seem perfectly clear and are apparently integrated. ${ }^{32}$

\footnotetext{
${ }^{30}$ Robert E. Scott, Chaos Theory and the Justice Paradox, 35 W \& M L. Rev. 329, 341 (1993); Richard Danzig, A Comment on the Jurisprudence of the Uniform Commercial Code, 27 Stan. L. Rev. 621 (1975).

${ }^{31}$ UCC Section 2-202, comment 1: "This section definitely rejects ...any premise that the language used has the meaning attributable to such language by rules of construction existing in the law rather than the meaning which arises out of the commercial context in which it was used. "See also, UCC Section 1-205, comment 1: "This Act rejects both the "lay dictionary" and the "conveyancers" reading of a commercial agreement."

${ }^{32} \mathrm{UCC}$ section 2-202 and comments 1, 2 (1994). "[W]ritings are to be read on the assumption that the course of prior dealings between the parties and the usages of trade were taken for granted when the document was phrased."
} 
Following the adoption of the Code, a number of common law courts (encouraged perhaps by the Second Restatement of Contracts ${ }^{33}$ ) have recognized informal commercial practices in the course of interpreting commercial services contracts. But the tide of expansive incorporation has not swept away the restrained approach of the common law tradition. Thus, the two systems continue in an uneasy coexistence and provide a unique opportunity to observe how different methods of institutional design influence the social benefits that inhere in uniformity.

\section{Substantive Uniformity Under the Code}

In this section, I evaluate the extent to which courts, adjudicating disputed sales contracts under the Code, have been successful in implementing the approach that Llewellyn seems to have envisaged: balancing the predictability (and standardization) benefits of uniform interpretation against the standardization benefits from activist incorporation.

The Increase in Interpretation Bias. The activist approach to incorporation adopted by the Code necessarily increases the stress on courts seeking to minimize errors in interpretation. Parties must communicate the express terms of their agreement through the inherently imperfect mediation of words, actions and other manifestations that admit of varying interpretations. As the arbiter of disputed interpretations, the state determines the meaning of whatever signals the parties exchange. While the state presumably knows what it means by the default rules that it implies in every contract, it does not know the intended meaning of the express terms chosen by the parties. Thus, privately formulated express terms are always subject to an additional risk of unpredictable (or nonuniform) interpretation. Contracting parties face an inherent risk that an express term that was designed to trump the default terms of the contract will be interpreted instead as merely supplementing the default understanding. ${ }^{34}$

\footnotetext{
${ }^{33}$ See Restatement (Second) of Contracts, sections 204, 221, 222, 223 (1979).

${ }^{34}$ See e.g., Publicker Indus., Inc. V. Union Carbide Corp., 17 UCC Rep. Serv. 989 (Pa. 1975); Missouri Pub. Serv. Co. v. Peobody Coal Co., 583 S.W. 2 d 721 (Mo. 1979).
} 
Casual observation strongly suggests that the risk of unpredictable interpretation has greatly increased for commercial parties under the Code. Courts under the Code have, consistent with its institutional design, interpreted the meaning of express terms in a contract by looking to precisely the same commercial and legal context they use to determine whether to incorporate custom and usage as default rules. ${ }^{35}$ Giving the commercial context interpretive priority over the verifiable express terms in the contract subverts the efforts of parties to opt out of ill-fitting defaults. Thus, for example, the Code directs courts to construe express terms and the commercial context as consistent with each other. ${ }^{36}$ While this presumption is limited by the corollary that inconsistent usages and experiences should give way, courts have frequently abandoned this principle on the grounds that there is almost always some contextual argument upon which seemingly inconsistent terms can be rationalized. In practice, therefore, the presumption of consistency in the Code has placed a considerable additional burden on parties seeking to opt out of either the legally-supplied defaults or the commercial context. ${ }^{37}$

The effects of interpretation bias under the Code are not limited to the error costs of unpredictable interpretation. A contextualized strategy of interpretation also undermines the ability of courts to increase over time the supply of officially recognized (and standardized) invocations and other express conventions. The abandonment by the Code of the plain meaning rule has resulted in decisions that strip terms of their meanings and thus erode the established menu of standardized express terms.

\footnotetext{
${ }^{35}$ See e.g., Brunswick Box Co. v. Coutinho, Caro \& Co., 617 F2d. 355 (4th Cir. 1980); Steuber C. v. Hercules, Inc. 646 F2d. 1093 (5th Cir. 1981); Nanakuli Paving \& Rock Co. v. Shell Oil Co., 664 F2d. 772 (9th Cir. 1981); Columbia Nitrogen Corp. v. Royster., 451 F2d. 3 (4th Cir. 1971); Modine Mfg. Co. v. North E. Independent School Dist., 503 S.W. d. 833 ( Tex. Civ.

App. 1975).

${ }^{36}$ UCC Sec. 1-205 (4) (1978).

${ }^{37}$ This interpretive error is both "unpredicted" and also "unpredictable". Courts sometimes commit the reverse error of interpreting express terms that seem intended by the parties as merely supplementary to the default assumptions as trumping those assumptions. Thus, the bias is both skewed in favor of the standard norms and uncertain in its application to particular cases. See (cite cases).
} 
In one illustrative case, the seller attempted to introduce evidence of a course of performance between the parties to suggest that the buyer had agreed to pay for unloading and storage charges. ${ }^{38}$ The court admitted the evidence despite the presence in the contract of an F.A.S. shipment term that, in standard meaning, requires the seller to pay for unloading and storage charges. The court apparently believed that it was incorporating the course of performance as a tailored default to redesign the somewhat ill-fitting conventional meaning attached to F.A.S by the Code. However, this legal recognition of a prevailing contextual pattern threatens the parallel process by which courts recognize (and standardize) similarly useful express signals of agreement. In order to protect standardized express terms from interpretive bias, the course of performance must be seen as trumped by the talismanic meaning attributed to the F.A.S term. After all, if parties are to use express invocations and conventions to trump default rules, the language they use for this purpose must be insulated from the context they are seeking to escape. On this view, an express invocation or convention selected by the parties can only be modified by additional express language. Otherwise, incorporation of the factual context will create a presumptive answer to the very question being asked.

The Results of the Incorporation Strategy. The increase in interpretation bias reflected in decisions by courts under the Code is predicted by the analysis developed earlier in Part I. The central question remains: is the reduction in the benefits from predictable interpretation and the resulting reduction in the supply of standardized express terms justified by the offsetting gains resulting from the incorporation of useful defaults from the commercial context?

While the Code was explicitly designed to incorporate evolving norms into an ever growing set of legally defined default rules, incorporation as such has simply not occurred. To be sure, courts have interpreted disputed contracts in which context evidence has been evaluated together with the written terms of the contract. The invitation to contextualize the contract in this

\footnotetext{
${ }^{38}$ Brunswick Box Co. v. Coutinho, Caro \& Co., 617 F. d. 355 (4th Cir. 1980).
} 
manner is explicitly embodied in the Code's definition of "agreement", ${ }^{39}$ and it is amplified by section 1-205(3), which specifies that courses of dealing and usages of trade give particular meaning to, and qualify terms of, an agreement. ${ }^{40}$ But while judicial decisions affirm the institutional bias toward contextualizing the contract, the fact-specific nature of the contract dispute leaves, in virtually every case, little opportunity for subsequent incorporation as tailored defaults.

The limited role played by usage and course of dealings per se is not surprising. These disputes always arise as interpretive disputes over the meaning of express terms and particular usages and not as the means of specifying a more precise or tailored meaning of the substantive obligations embodied in the Code's numerous default rules. The vehicle for this latter aspect of the incorporation project, in Llewellyn's mind, was the pervasive direction to courts (found in a majority of the specific provisions of Article 2) to apply the default provision in question according to the norm of commercial reasonableness. ${ }^{41}$

The supereminent norm of commercial reasonableness was seen by Llewellyn as a key incorporating mechanism; one that would function as an empirical direction. To decide if the parties have acted in a commercially reasonable manner as to any particular contractual obligation, the court is asked to look to the commercial environment and observe the relevant commercial

\footnotetext{
${ }^{39}$ UCC section 1-102(3) defines " agreement" as "the bargain of the parties in fact as found in their language or by implication from other circumstances including course of dealing or usage of trade or course of performance as provided in this Act."

${ }^{40}$ UCC section 1-205(3) (1994) Comment 1 to section 1-205 provides that: This act rejects both the "lay-dictionary" and the "conveyancer's" reading of a commercial agreement. Instead the meaning of the agreement is to be determined by the language used by them and by their action, read and interpreted in the light of commercial practices and other surrounding circumstances. The measure and background for interpretation are set by the commercial context, which may explain and supplement even the language of a formal or final writing.

${ }^{41}$ The norm of commercial reasonableness is variously expressed in Article 2, sometimes just with the injunction "reasonable", but always directed to or qualified (usually explicitly) by a broader reference to commercial practice. See e.g., sections 2-103(1)(b), 2-204, 2-205, 2-206, 2-208, 2-305, 2-308, 2-309, 2-311, 2-402, 2-503, 2-510, 2-513, 2-603, 2-604, 2-605, 2-607, 2-608, 2-609, 2-610, 2-614, 2-706, 2-709, 2-710, 2-712, 2-714.
} 
behavior. Once revealed (and mediated through the normative "purposes" of the Code), this standard would then provide the legal norm to be published as an appropriately tailored default for the relevant class of contracting parties. $^{42}$

Thus, for example, section 2-609 provides that "when reasonable grounds for insecurity arise with respect to the performance of either party the other may in writing demand adequate assurances of due performance and until he receives such assurances may if commercially reasonable suspend his own performance..." ${ }^{43}$ Generations of law students have begun their study of the Code by confronting the facially vacuous nature of that default provision. As a majoritarian default, it offers little in the way of a standardized contractual risk assignment since it carries no predictable meaning. But Llewellyn understood this point as well. Section 2-609 was never intended to operate as a useful default on its face. Rather, the key instructions-- "adequate assurances", "reasonable grounds for insecurity" and "commercially reasonable" suspension-were intended to direct courts to examine the relevant contracting environment and then (presumably over time) publish meaningfully tailored defaults that would apply to particular populations of commercial parties.

This was a revolutionary idea, and one that seemed to anticipate the theoretical objection to state-supplied default rules raised by the recent literature on incomplete contracting. But the project has failed in implementation. Systematic examination of the litigated cases interpreting the Code's "reasonableness" standards reveals that courts have consistently interpreted these statutory instructions not as inductive directions to incorporate commercial norms and prototypes but rather as invitations to make deductive speculations according to "Code policy" or other non-

\footnotetext{
${ }^{42}$ A. Schwartz \& R. Scott, Commercial Transactions: Principles and Policies 5 (1981).

${ }^{43}$ UCC section 2-609 (1994).
} 
contextual criteria. ${ }^{44}$ I evaluate the reasons for the failure of the Code's incorporation strategy in

Part III. But the empirical point is that, for whatever reason, courts charged with the

responsibility of implementing the Code's activist policy towards incorporation have declined to

do so. ${ }^{45}$

Thus, the costs of a strategy of incorporation-- a highly contextualized interpretive

${ }^{44}$ A LEXIS search for cases of the past ten years which invoke commercial reasonableness in close conjunction with mention of at least one Article two section returned one-hundred and sixty-four hits. A detailed examination of fifty-five cases randomly selected from the this base pool revealed two cases where the court viewed the commercial reasonableness question as requiring inductive evaluation. See Havird Oil Co. V. Marathon Oil Co., 149 F.3d 283 (4th 1998); Cattle Fin. Co. v. Boedery, Inc., 795 F. Supp. 362 (D. Kan. 1992). In eighteen other cases a deductive approach was used in the evaluation of commercial reasonableness. See Meyer v. Norwest Bank Iowa, 112 F.3d 946 (8th 1997); U\&W Indus. Supply v. Martin Marietta Alumina, Inc., 34 F.3d 180 (3d 1994); Bausch \& Lomb, Inc. v. Bressler, (2d 1992); Bill's Coal Co. v. Board of Pub. Utils. Of Springfield, 887 F.2d 242 (10th 1989); Canusa Corp. v. A\&R Lobosco, Inc., 986 F. Supp. 723 (E.D.N.Y. 1997); Spanierman Gallery Profit Sharing Plan v. Arnold, 1997 U.S. Dist. LEXIS 3547 (S.D.N.Y. Mar. 27, 1997); Waldorf Steel Fabricators v. Consolidated Sys., 1996 U.S. Dist. LEXIS 12340 (S.D.N.Y. Aug. 23, 1996); Wayman v. Amoco Oil Co., 923 F. Supp. 1322 (D. Kan. 1996); RW Power Ptnrs., L.P. v. Virginia Elec. \& Power Co., 899 F. Supp. 1490 (E.D. Va. 1995); Twin Creeks Entertainment, Inc. v. U.S. JVC Corp., 1995 U.S. Dist. LEXIS 2413 (N.D. Ca. Feb. 22, 1995); BAII Banking Corp. v. ARCO, 1993 U.S. Dist. LEXIS 14107 (S.D.N.Y. Oct. 7, 1993); J. Moreria, LDA. v. Rio Rio, Inc., 1992 U.S. Dist. LEXIS 19088 (S.D.N.Y. Dec. 15, 1992); Larsen Leasing v. Thiele, Inc., 749 F. Supp. 821 (W.D. Mich. 1990); Danish Fur Breeders Assn. v. Olga Furs, Inc., 1990 U.S. Dist. LEXIS 4779 (S.D.N.Y. Apr. 24, 1990); In re Narragansett Clothing Co., 138 B.R. 354 (Bankr. D.R.I. 1992); Bockman Printing \& Servs. v. Baldwin-Gregg, Inc., 572 N.E.2d 1094 (Ill. App. Ct. 1991); Touch of Class Leasing v. Mercedes-Benz Credit of Canada, Inc., 591 A.2d 661 (N.J. Super. Ct. App. Div. 1991); Hornell Brewing Co. v. Spry, 664 N.Y.S.2d 698 (N.Y. Sup. Ct. 1997). Of the remaining thirty-five cases, nineteen touched only tangentially upon the issue of commercial reasonableness, while sixteen dealt principally with commercial reasonableness under other sections of the Code or other areas of the law, e.g., Articles 2A, 3, 9 and common law real property. See also Imad D. Abyad, Note, Commercial Reasonableness in Karl Llewellyn's Uniform Commercial Code Jurisprudence, 83 Va. L. Rev. 429 (1997), for a systematic review of the interpretation and use by courts of the supereminent notion of commercial reasonableness under the Code. Abyad finds that courts predominantly apply a deductive approach to the determination of commercial reasonableness. But he also notes and examines some striking exceptions to this general rule in courts' treatment of certain provisions within Articles 3 and 9 of the Code.

${ }^{45}$ It is a separate and independent question whether, had the results of the Code's experiment with incorporation been different, the tailored defaults that were announced and standardized would have been either optimal or efficiently promulgated by courts. See Jody Kraus, Legal Design and the Evolution of Commercial Norms, 26 J. Legal Stud. 377 (1997) (arguing that evolutionary norms are not likely to be optimal and suggesting the continuing utility of intelligent institutional design). See also Robert E. Scott, A Relational Theory of Default Rules for Commercial Contracts, 19 J Legal Stud. 597 (1990) (suggesting that a positive explanation for the absence of tailored defaults lies in the parties' preferences to be governed under separate regimes of bright-line majoritarian default rules and flexible extralegal norms that are not legally enforceable. "It may be that the great lesson for the courts is that any effort to judicialize these social rules will destroy the very informality that make them so effective in the first instance". Id at 615); Lisa Bernstein, Merchant Law in a Merchant Court: Rethinking the Code's Search for Immanent Business Norms, 144 U. Penn. L. Rev. 1765 (1996) (same). 
methodology that seeks to embed the explicit terms of a contract within a larger commercial context-- seem not to be justified by corresponding enhancements in the supply of useful defaults for appropriate subsets of commercial contractors. At least according to the uniformity criteria developed above, the results of thirty of codified uniformity suggest that formal uniformity has masked a general deterioration in the efficiency values that stimulated the search for a uniform law in the first instance. The final question, of course, is whether the parallel experience of courts regulating incomplete commercial services contracts under the common law has been more or less "uniform" than the results under the Code.

\section{Substantive Uniformity under the Modern Common Law}

It is striking to contrast the experiment in codified uniformity with the experience of common law enforcement of commercial services contracts over the same forty year period. The interpretive methodology of the common law has stubbornly resisted the contextual interpretation adopted by the Code and the Second Restatement of Contracts. The overwhelming majority of jurisdictions continue to adhere to textualist interpretation of contract terms, primarily through a rigorous adherence to the plain meaning rule. Indeed, the continuing vitality of the traditional parol evidence and plain meaning rules cannot be overestimated. ${ }^{46}$ In numerous cases, common law courts interpreting commercial contracts have been unwilling to accept the implications of contextualization; in one guise or another they continue to invoke the primacy of express, verifiable contract terms and of the written agreement between the parties.

\footnotetext{
${ }^{46}$ See, e.g., Watkins v. Pedro Search, Inc., 689 F. d. 537 (1982) (unambiguous writing will be accorded the meaning apparent on its face; objective and not subjective intent controls); Mellon Bank v. Aetna Business Credit, Inc, 619 F. d. 1001 (3d Cir. 1980) (same); Lee v. Flintkote Co., 593 F. 2d 1275 (D.C. Cir. 1979) (plain meaning rule bars evidence of meaning of unequivocal contract terms); Reed, Wible \& Brown, Inc. v. Mahogany Run Dev. Co., 550 F. Supp. 1095 (M.D. La. 1982) (same); Acree v. Shell Oil Co., 721 F. d. 524 (5th. Cir. 1983); William B. Tanner Co. v. Sparta-tomah Broadcasting Co., 543 F. Supp. 593 (W.D. Wis. 1982) (unambiguous contract language should be given its plain meaning, with no need to consider extrinsic evidence or rules of construction); Berry v. Klinger, 225 Va. 201 (1983) (plain meaning rule controls interpretation of unambiguous written contract) (same result in New York, North Carolina, Illinois, Oklahoma and Pennsylvania, see cases cited in Goetz \& Scott, The Limits of Expanded Choice, 73 Calif. L. Rev. at n. 124)
} 
Two uniformity values are served by the common law courts' insistence on preserving the traditional approach to contractual interpretation. First, a rigorous application of the plain meaning rule reduces the errors caused by unpredictable interpretations of incomplete contracts by encouraging parties to use clearer, pre-defined signals of the reasons for contractual incompleteness. Second, plain meaning interpretation facilitates that portion of the standardization function that derives from the recognition of customary express terms. These terms then carry a standard meaning whenever they are used, even if their use is not so customary as to warrant automatic incorporation as default rules. ${ }^{47}$ Over time, the legal recognition of certain talismanic words and phrases greatly facilitates the contracting process. Definitional recognition does not change the optional character of these terms, but it does confer upon them the status of invocations or conventions so that, once expressly incorporated into a contract, they will have a legally circumscribed meaning that will be heavily and perhaps even irrebuttably presumed.

As one might predict, a study of the evolving common law of commercial services contracts does not reveal the incorporation by courts of novel default rules. Incorporation is stymied by an interpretive methodology that systematically excludes reference to the commercial context. But the past forty years has nonetheless seen a remarkable harmonization in standardized terms through the development of a rich menu of express invocations and conventions. ${ }^{48}$ Standardization of express terms has been stimulated in construction contracting, for example, through the offices of key intermediaries such as the American Institute of Architects. These and

${ }^{47}$ See Goetz \& Scott, Expanded Choice, supra note --- at ---. See also, Eric Posner, The Parol Evidence Rule, The Plain Meaning Rule, and the Principles of Contractual Interpretation, 146 U. Pa. L. Rev. 533 (1998).

${ }^{48}$ Apt examples of standardized invocations are "Incoterms", the international rules for the interpretation of trade terms. See International Commerce Comm'n, Incoterms (1980). Each of the fourteen Incoterms attempts to set forth a number of substantive rules. These rules were well-known and widely used terms of international trade before their formal codification by the International Chamber of Commerce. Examples of conventions include corporate indentures, bond covenants and most of the standard features of corporate financial agreements. See generally, Marcel Kahan \& Michael Klausner, Standardization and Innovation in Corporate Contracting (OR “The Economics of Boilerplate:), 83 Va. L. Rev. 713 (1997) 
other trade organizations have developed and promulgated model contract terms and forms which are widely and successfully used by parties to construction contracts and which have been subject to remarkably uniform interpretation by state courts. These model or standard forms provide a mechanism for internalizing at least some of the benefits from contractual innovation and standardization that private parties are otherwise unable to capture. In instances where the trade organization represents a significant subset of the potential users of the standard terms, it can supply the coordination necessary to overcome the collective action problems discussed earlier.

Industry codes have also played a significant role in the development of novel uniform terms to respond to changing conditions within certain markets. ${ }^{49}$ Perhaps surprisingly, the maintenance of rigorous rules of objective interpretation seems to have stimulated the development of novel standard terms by trade groups and other intermediaries. These kinds of standardized options have been far slower to develop under the Code. Indeed, Lisa Bernstein notes the phenomenon of a key commercial subgroup under the Code--The National Grain and Feed Association-- choosing to opt out of the Code entirely in order to secure the kind of plain meaning interpretations necessary to the promulgation of standardized norms. ${ }^{50}$

Thus, the common law regulation of commercial contracts seems to have created a hospitable legal environment, one that facilitates the development of intermediaries to overcome the collective action problems that otherwise retard the development of novel uniform terms. Moreover, additional harmonization of non-code commercial law has resulted from the jurisdictional diversity that the Code drafters sought so vigorously to overcome. New York, for example has solidified its position as the jurisdiction of choice for commercial contractors by

\footnotetext{
${ }^{49}$ See. e.g., the responses of both the American Institute of Architects and the Associated General Contractors to the need to develop uniform rules governing fast track construction management contracting. American Inst. of Architects, General Conditions of the Contract for Construction, Docs. Nos. A101/CM, A201/CM, B141/CM, B801(1980); Associated Gen Contractors, Standard Form of Agreement between Owner and Construction Manager, Doc. No. 8a (1977), 8d (19790, 8 (1980).

${ }^{50}$ Bernstein, supra note --- at ---.
} 
enacting a choice of law selection statute that permits parties ex ante to choose New York contract law as the uniform source of interpretation. ${ }^{51}$

In addition to the temporal benefits from uniformity, there are efficiency gains that inhere in jurisdictional uniformity. Prime among these are "learning effects" that result from a common legal language and method of categorization of legal rules. ${ }^{52}$ Here the formal uniformity of the Code might seem to offer a significant advantage over the common law. Indeed, the notion of a uniform "filing system" that permits the storage and retrieval of key legal information remains one of the strongest justifications offered by Karl Llewellyn for a uniform sales law. ${ }^{53}$ Under the Code's cataloguing system, specific court decisions are filed under the broad rubrics of Codedefined categories such as rejection, cure, etc. Systematizing the retrieval of legal rules reduces the learning effects imposed by jurisdictional diversity. Presumably, information costs would be greater if the decisions were not organized in a systematic way.

Despite the jurisdictional diversity that remains under the common law, there is reason to believe that learning effects and legal information costs are not significantly greater than under the Code. Economic and cultural forces may well have contributed to the evolution of interjurisdictional substantive uniformity during this same period. Indeed, the past forty years have witnessed a remarkable degree of harmonization of American commercial common law. The variations in contract law from state to state today are relatively small and insignificant. There are few instances where a state persists over time in applying a widely variant "rule" of contract law. The result is "substantive harmony without uniformity." 54

\footnotetext{
${ }^{51}$ find cite
}

${ }^{52}$ See generally, Michael Klausner, Corporations, Corporate Law, and Networks of Contracts, 81 Va. L. Rev. 758 (1995).

${ }^{53}$ Karl Llewellyn (get cite: Florida or Florida State Law Review, late 1950's)

${ }^{54}$ Arthur Rosett, Unification, Harmonization, Restatement, Codification, and Reform in International Commercial Law, 40 Am. J. Comp. L. 683 (1992). 
This result should not be surprising. Powerful market forces push toward harmonization across jurisdictions. Judges, especially in commercial cases, want to please the practicing bar; they benefit from favorable evaluations of their work from insiders. The practicing bar, meanwhile, prefers law that is (1) predictable, so that they are better able to advise their clients, and (2) substantively right, insofar as there is a substantively right answer. Quite obviously, these two factors coalesce. Where the law is uncertain, but there is a strong substantive case for one legal rule rather than another, the practicing bar would like to be able to predict the outcome by discerning the substantively better rule. Thus, both factors push toward harmonization, probably with a tendency to follow those state courts with special expertise and prestige. In short, while the risks of casual empiricism argue for tentativeness in advancing empirical claims, nevertheless all the available evidence points to the fact that the Uniform Commercial Code has been far less successful than the common law alternative in promoting the efficiency values of uniformity. 


\section{NORMATIVE IMPLICATIONS: THE CAUSES AND EFFECTS OF THE FAILURE OF CODIFIED UNIFORMITY}

Why has the experiment with codified uniformity performed so poorly in terms of the substantive objectives of a uniform law? And what are the effects of that failure? In this Part, I explore both of these questions.

\section{Why the Uniform Code has Failed to Produce Substantive Uniformity}

The are doubtless many reasons for the failure of the Code to achieve the objectives of its drafters. Quite clearly, one central reason was the failure of the other Code drafters to adopt Llewellyn's proposal that commercial disputes under the Code be resolved by merchant juries. Llewellyn believed that a major purpose of the Code was to resolve disputes according the 'best' commercial norms. In his view, the task of the courts was to identify and select the best commercial prototypes that were revealed in a particular commercial environment. One obvious objection to this strategy, of course, is that courts lack the expertise to observe and evaluate merchant practice. To respond to this concern, Llewellyn designed the supereminent norm of commercial reasonableness as an empirical direction: to delegate discretion to expert bodies, not judges and lay jurors. ${ }^{55}$ Eliminating the merchant jury while retaining the pervasive notion of commercial reasonableness was, in consequence, a drafting disaster.

But the failure to provide for the merchant jury is but a symptom of a larger jurisprudential mistake for which Llewellyn must be held at least partly responsible. Llewellyn believed that moral norms can be derived from actual practices. But how is this to be accomplished? After all, the evaluator must have some moral criteria, derived independently from the practice, in order to

\footnotetext{
${ }^{55}$ See Note, Commercial Law and the American Volk: A Note on Llewellyn's German Sources for the Uniform Commercial Code, 97 Yale L. J. 156 (1987).
} 
extract the "ought" from the "is". ${ }^{56}$ For example, assume a court is faced with the question of good faith in the case of a merchant under section 2-103(1)(b). ${ }^{57}$ The subject of the dispute is the merchant's business practice which is followed by some, but not all, of the participants in the trade. Whether this practice reflects "the observance of reasonable commercial standards of fair dealing in the trade" cannot be answered by the mere existence of the practice. The court must, therefore, have some criteria, derived independently from the practice, by which to decide whether the practice is " reasonable" and "fair" under the legal standard.

It seems quite clear that this point was not lost on Llewellyn either. He had an answer: the moral norms used to sort good practices from bad ones were to come from the purposes of the Code itself. Llewellyn, like most realists, wanted courts to choose purpose over rule language: to do this is to judge in the "grand style". 58 Thus, Llewellyn wanted particular Code sections interpreted in light of the purposes underlying the Code itself. This preference explains, in part, the decision to retain the supereminent norm of reasonableness even after the proposal for merchant juries was abandoned. Llewellyn wanted courts to understand that it was desirable to decide specific cases in light of the Code's general purposes. To do that, he joined, enthusiastically, those of his colleagues who were promoting (for instrumental reasons) ${ }^{59}$ the idea of a "true commercial code" to replace the checkered pastiche of prior uniform statutes. Thus, instrumental and jurisprudential considerations were united. ${ }^{60}$

\footnotetext{
${ }^{56}$ To do otherwise requires overcoming a naturalistic gap. It risks committing what arguably is the naturalistic fallacy. See G.E. Moore, Principia Ethica 10-14 (1971 ed.). For a recent assessment which doubts the existence of the fallacy, see Stephen Darwall, Allan Gibbard \& Peter Railton, Toward Fin de Siecle Ethics: Some Trends, 101 Phil. Rev. $115,115-120$ (1992).

${ }^{57}$ UCC section 2-103(1)(b) provides that " 'good faith' in the case of a merchant means honesty in fact and the observance of reasonable commercial standards of fair dealing in the trade."

${ }^{58}$ See Karl Llewellyn, The Common Law Tradition (1960).

${ }^{59}$ See discussion supra at---.

${ }^{60}$ The decision to create a true code was combined with the political instincts not to publicize the project as a codification. William Hawkland, who served as Llewellyn's research assistant, suggests that if Llewellyn had publicized his intention to codify the commercial law, the UCC would "probably have died aborning". William Hawkland, The
} 
The decision to create a true code was a fateful one. ${ }^{61}$ A central difference between the uniform commercial statues that preceded the UCC and the new Code lay in the different interpretive methodologies that are dictated by a code. A code is a preemptive, systematic and comprehensive enactment of a whole field of law. ${ }^{62}$ It presumes to carry within it the answers to all possible questions. Thus, when a court confronts a gap in an incomplete contract, its duty in interpreting a code is to find by extrapolation and analogy a solution consistent with the purposes and policy of the codifying law. A code remains at all times its own best evidence of what it means. Thus, the decisions interpreting provisions of a code do not as easily become part of the understood meaning of its terms as they do in the case of an ordinary statutory enactment.

In order to accomplish its purposes, a code must have a systematic method of filling gaps by a self-referential process of divining the purposes of the enactment. In the UCC, this directive is found in section 1-102 which directs courts to liberally construe and apply the specific

Uniform Commercial Code and the Civil Codes, 56 La. L. Rev. 231, 233 (1995). But, nevertheless, a code by any other name......

${ }^{61}$ One can debate the point of whether or not the Code is a "true code". There is respectable academic argument either way. On the side of the "true code" advocates can be placed the strong set of normative principles to guide in Code interpretation that section 1-102 provides, the uniform jurisprudential underpinnings generated by systematic recourse to commercial context, and the pervasive reliance on "reasonableness and other supereminent norms. See e.g. Richard Buxbaum, Is the Uniform Commercial Code a Code?, Rechtsrealismus, multikulturelle Gesellschaft und Handelsrecht, 197, 220 (Duncker \& Humbolt, Berlin 1994). (arguing that the UCC is a code "within the American frame of reference"); William Hawkland, Uniform Commercial "Code Methodology, 1962 U. Ill. L.F. 291 (1962) (same). On the other side, one can invoke section 1-103 which purports to make the UCC dependent on extraUCC law. See Homer Kripke, 1962 U. Ill. L.F. ---(1962).

But section 1-103 is a slim reed on which to hang the argument that the Code is not a "code". The provision does not operate as a dynamic incorporation mechanism. Recourse to the law merchant and to the "law relative to capacity to contract, principal and agent, estoppel, fraud, misrepresentation, duress, coercion, mistake, bankruptcy, or other validating or invalidating cause" is only appropriate "unless displaced by the particular provisions of this Act". Section 1-102, which specifies liberal construction to promote the underlying policies of clarification, expansion of commercial practices and uniformity, is precisely the sort of "particular provision" which displaces the common law. Thus, the primary effect of section 1-103 is to incorporate non- controversial default rules and subject them to the very same interpretive methodology that influences the interpretation of the Code-supplied defaults. In the sense that it matters here, therefore, the Code is a "true" Code in that it has a self-contained mechanism for interpretation and expansion of internally generated rules and principles of interpretation.

${ }^{62}$ Hawkland, note --- supra at 235 et seq.; William D. Hawkland, Uniform Commercial “Code” Methodology, 1962 U. Ill. L.F. 291 (1962). 
provisions of the act "to promote is underlying purposes and policies." 63 The effect of this language is that the Code not only has the force of law, but it is itself a source of law. ${ }^{64}$ In important respects, therefore, Llewellyn's Code displaced the legal method of the common law and substituted the legal method of the civil law.

To construct the Code in the tradition of continental codifications required the development of supereminent "safety valve" provisions designed to fill gaps and to mitigate the harshness of bright line rules that would otherwise be asked to govern "hard" cases. ${ }^{65}$ Gaps are to be filled through recourse to the purposes enumerated in the Code and, in specific provisions, by recourse to the overarching injunction to follow the norms of "reasonableness". The net effect of this institutional design is a highly contextualized interpretive methodology, one that seeks to embed the explicit terms of a contract within the larger jurisprudential context of the Code as well as within the specific commercial context being regulated.

The result, in terms of maximizing the benefits of substantive uniformity, could hardly have been much worse. First, the rejection of the common law plain meaning and parol evidence rules was an open invitation to courts to abandon any meaningful constraints on the interpretation of language. Over time, the uniformity value of predictable interpretation has been eroded. While courts under the Code are uniformly using the same interpretive rules, the results they reach are anything but uniform. Thus, the Code quite self-consciously has squandered whatever efficiency gains are achievable through uniform, objective methods of contract interpretation.

${ }^{63}$ UCC Section 1-102 (1994). One of the profound ironies of the Code is that among the enumerated purposes of section 1-102 is to "make uniform the law among the various jurisdictions". The very provision that led to this purpose being fulfilled in a formal sense create the seeds for failure in a substantive sense.

${ }^{64}$ Mitchell Franklin, On the Legal Method of the Uniform Commercial Code, 16 Law \& Contemp. Prob. 330, 333 (1951). This claim seems confirmed by Comment I to section 1-102: "This Act is drawn to provide flexibility...to make it possible for the law embodied in this Act to be developed by the courts in the light of unforseen and new circumstances and practices."

${ }^{65}$ Hawkland, supra at -----. 
Second, the standardization process has failed to evolve. Recall that standardization comes in two forms: the promulgation of useful default rules by incorporating commercial practice into commercial law and the official recognition and interpretation of customary terms in a menu of invocations and conventions. Neither of these processes has occurred with the same vigor in the Code as in the parallel common law process.

One reason for the unwillingness of the courts to embrace incorporation may be the lack of information regarding the effects of novel, tailored defaults in different settings and among heterogenous parties. But another reason seems to be the peculiar distortions created by code methodology: courts are required to create default rules with reference to the hermetic regulatory framework of the Code itself. The process of Code interpretation inevitably resists the dynamic process inherent in standardization. ${ }^{66}$ A comprehensive Code means that, for any given issue, courts will be driven to adopt a rule that will then be treated as, in effect, a part of the Code. Parties under the Code are thereby pushed toward arguments that are based on one or another "Code rule". Contracting out of the rule, in turn, is made difficult by the widespread abandonment by the Code of the parol evidence and plain meaning rules. Thus, code methodology tends to produce a static equilibrium that impedes the evolution and promulgation of novel default rules and contract terms. ${ }^{67}$ Under the common law, on the other hand, the parol evidence and

${ }^{66}$ See text supra at ---. Recall that efficient standardization requires not only that the present stock of standard terms and default be preserved but that, as they become incrusted with rote usage over time and as new practices develop that demand new legal arrangements, the standardization process evolves new forms and coordinates the move to the novel terms. See Goetz \& Scott, The Limits of Expanded Choice, supra note --- at ---.

${ }^{67}$ Another virtue of the common law versus the Code, given these factors, is that litigation and legal argument is much less costly under the common law scheme. For example, as between context-free arguments about what "F.A.S." ought to mean, and arguments about what the relevant commercial customs are, the former are significantly cheaper than the latter. Moreover, litigating commercial reasonableness is costly in another way--there is a substantial error cost, a risk that courts will not get the custom right. Commercial arrangements, after all, are anchored in industries with which courts may have little familiarity.

The combination of these costs quite probably impel some commercial actors to invest, not in producing evidence and argument about new commercial customs for incorporation into the Code, but rather in avoiding the Code altogether, by arbitration or choice-of-law agreements or by other, more informal, means. In sum, perhaps the Code doesn't incorporate new defaults because the mechanism by which the defaults are produced is too costly and that cost drives parties more to litigation avoidance than to law production. See infra at----. 
plain meaning rules make it fairly easy for parties to generate new terms which can then acquire standard interpretations. Those sorts of legal rules are not so enveloping; they are significantly easier to opt into or out of.

\section{The Effects of a 'Nonuniform' Uniform Code}

The promulgation of a uniform code that reduces rather than enhances the economic benefits from uniformity has had several significant effects. The first is the observed practice of groups of commercial parties opting out of the Code entirely in important classes of cases. Lisa Bernstein notes an important illustration: the decision by the members of the National Grain and Feed Association to opt out of the Code and create a private legal system to resolve contract disputes among their members. ${ }^{68}$ One of the principal reasons for the Association's decision to abandon the Code was their desire to have written express terms subject to a formalist and objective interpretive methodology and not to be trumped by relevant evidence of course of dealing or usage of trade. Bernstein suggests that the explanation for this practice lies in the parties desire to separate the legal norms that govern their written agreements from the informal social norms that govern their actions. ${ }^{69}$ An alternative (and complementary) explanation, however, is that opting out of the Code permits the grain and feed merchants to secure the economic benefits of uniformity by substituting a private common law process for the statesubsidized mechanism under the Code.

Whether the practice of opting out of the Code by homogeneous groups of commercial parties reflects an underlying inefficiency in the law is, of course, an empirical question. We would have to know how widespread is the practice that Bernstein and others have observed

\footnotetext{
${ }^{68}$ See Bernstein, supra note---.

${ }^{69}$ Bernstein, supra note-- at--. I advanced this explanation for the dichotomy between bright line default rules and flexible commercial practice in an earlier paper. See Scott, A Relational Theory of Default Rules, supra note--- at 613-615.
} 
before passing judgment on the Code's inefficiency. ${ }^{70}$ Nevertheless, the evidence is sufficiently striking to undermine the uncritical assumption of the academic and professional proponents of the Code that it serves efficiently its purported purposes.

The second effect of the stasis in the supply of Code defaults is even more dramatic. The principal source of novelty in the supply of Code default rules has been through the agonizing process of Code revision by legal academics and practitioners under the auspices of the ALI and NCCUSL. Technological change and the need for new legal instruments to accommodate that change has been one of the driving forces behind the current revision of the UCC. Electronic funds transfers, for example, stimulated revisions in Articles 3 and 4. Changing business practices led to Article 2A and revisions in Articles 5, 6, 8 and 9. ${ }^{71}$ Article 2, the provision most clearly designed by Llewellyn to evolve through dynamic renewal, has been in the process of being revised for the past decade with no end in sight.

Relying on the private legislative process that produces Code revisions to provide a new generation of useful default rules is worrisome on several grounds. First, the process is slow, cumbersome and costly. To the extent that there is a lag in the evolution of new contractual standards, parties with emerging needs face a difficult choice. Either they can rely upon ill-fitting

\footnotetext{
${ }^{70}$ There are other illustrations of commercial parties opting out of ill-fitting default rules by developing standard terms that create customized risk allocations. Perhaps the best example is the common practice in the purchase and sale of hard goods of contract terms that trump the Code's warranty scheme for allocating quality risks as well as the Code's scheme for stimulating optimal salvage decisions through the mechanism of rejection/ acceptance/ cure, etc. In the place of Code warranties and the rules for acceptance, rejection, cure and revocation, parties who trade in hard goods substitute standardized "repair and replacement" clauses. Such clauses purport to divide quality risks between buyer and seller to displace the default rules governing revocation of acceptance and cure (and perhaps rejection as well). See A. Schwartz \& R. Scott, Sales Law and the Contracting Process 204-209,308-309 (1991). Unfortunately, the standard repair and replacement clauses have been subject to widely disparate interpretations by courts, producing exactly the kinds of jurisdictional uncertainty costs that the Code was designed to reduce. Compare e.g., Myrtle Beach Pipeline Corp. v. Emerson Electric Co., 843 F. Supp 1027 (D. S.C. 1993) with Earl M. Jorgensen Co. v. Mark Construction, Inc., 540 P2d 978 (Haw. 1975) and International Financial Services, Inc. v. Franz, 23 UCC Rep 2d 1078 (Minn. 1994) with Chattlos v. NCR, 635 F.2d 1081 (3d Cir. 1986).

${ }^{71}$ Fred H. Miller, Realism Not Idealism in Uniform Laws-Observations from the Revision of the UCC, 39 So. Tex. L. Rev. 707 (1998)
} 
rules and/or standard terms that secure less than maximum trading gains or they can incur the costs of crafting new forms of agreement that are better adapted to the evolving conditions. To the extent that Code methodology impedes the development of intermediaries to internalize some of the costs of innovation, commercial parties are often left with the option of lobbying in the revision process as the only viable response to the problem of lags.

Lobbying by interest groups of the private legislative bodies that revise the Code raises a further set of concerns. Recent work on the political economy of private law making bodies suggests that the rules produced by these private legislative bodies are more driven by institutional factors than by their social desirability. ${ }^{72}$ There are good reasons to believe that private law making bodies such as the ALI and NCCUSL will have a strong status quo bias and will sometimes be captured by powerful interests. More importantly, the legal rules that are the products of these private legislative processes will sometimes be characterized by vague and imprecise rules not because those rules are optimal but because of a particular institutional dynamic.

In the case of Article 2, this analysis predicts that, despite the economic advantages of a return to the common law approach to uniformity, the revision to Article 2 will continue contain the same methodological characteristics as its predecessor: many vague rules that invoke the animating purposes of the Code coupled with open-ended, contextual modes of interpretation. These rules will dominate, not because of their intrinsic virtues, but because they are proposed by reformers (i.e., legal academics) who are unable to get clear, bright-line rules enacted and, since the effects of sales law do not fall systematically on any interest group, there are insufficient incentives for organized interest groups to lobby for bright-line rules in their favor. ${ }^{73}$

\footnotetext{
${ }^{72}$ See Alan Schwartz \& Robert E. Scott, The Political Economy of Private Legislatures, 143 U. Pa. L. Rev. 595 (1995); Robert E. Scott, The Politics of Article 9, 80 Va. L. Rev. 783 (1994). For applications of this analysis to international law making, see Paul Stephan, Accountability and International Lawmaking: Rules, Rents and Legitimacy, 17 Nw. J. Int'1 L. \& Bus. 681 (1997).

${ }^{73}$ See Schwartz \& Scott, The Political Economy of Private Legislatures, supra note-- at --.
} 
These predictions seem to be confirmed in the work to date of the Article 2 Drafting Committee. According to the Reporter of the Drafting Committee, the Committee "has preserved the original approach to contract formation and interpretation attributable to Karl Llewellyn. This approach minimizes formality...[t]he emphasis is upon flexible standards, mutual conduct and the intention of the parties." ${ }^{.74}$ In all likelihood, therefore, the Revised Article 2 will not address the underlying causes of the failure to achieve substantive uniformity. Even if most contracting parties would benefit from an institutional design that promoted the objective interpretation of express contract language and the recognition and promulgation of privately-developed standard terms, there are good reasons to believe that the institutional dynamic of the law making process will result in a recodification of the status quo. Whether it is socially optimal or not, opting out of the Code and into the common law may be the only recourse for cohesive, homogeneous commercial groups.

\footnotetext{
${ }^{74}$ Richard E. Speidel, Contract Formation and Modification Under Revised Article 2, 35 Wm \& Mary L. Rev. 1305, 1311 (1994).
} 